Article

\title{
Ecolabelling in the Romanian Seaside Hotel Industry-Marketing Considerations, Financial Constraints, Perspectives
}

\author{
Alina Barbulescu ${ }^{1, *}$, Andreea-Daniela Moraru ${ }^{2}$ (D) and Cristina Duhnea ${ }^{2}$ (D) \\ 1 Faculty of Mathematics and Informatics, Ovidius University of Constanta, 124 Mamaia Bd., \\ 900527 Constanta, Romania \\ 2 Faculty of Economic Sciences, Ovidius University of Constanta, 124 Mamaia Bd., 900527 Constanta, \\ Romania; moraru.ad@gmail.com (A.-D.M.); cristinaduhnea@gmail.com (C.D.) \\ * Correspondence: emma.barbulescu@yahoo.com; Tel.: +40-241-606462
}

Received: 17 September 2018; Accepted: 3 January 2019; Published: 7 January 2019

\begin{abstract}
The tendency to implement diverse environmental tools and promote the adoption of environmentally friendly practices in tourism activities is relatively new. One such tool is the EU Ecolabel used in the hotel industry as a voluntary European initiative meant to attest to the responsible attitude towards the environment. Since holding the ecolabel by the Romanian accommodation units is rather an exception, our aim was to investigate the views of industry managers on environmental issues, focusing on the EU Ecolabel, and get a glimpse of the challenges and prospects of ecolabelling within the seaside hotel industry. To this end, the study was designed and conducted on 60 hotel managers. The research results gave evidence to the measures already implemented, those pending implementation, reasons for not applying for the EU Ecolabel, and the most challenging criteria. The potential impact of the EU Ecolabel on the economic activity efficiency, and its role in customer decision processes and in marketing communication, was highlighted. Subsequently, a mathematical model was proposed, revealing that the intention to meet the criteria and obtain the EU Ecolabel depends on the managers' level of knowledge of the EU Ecolabel, their opinion on whether holding the EU Ecolabel represents a competitive advantage, and the current efficiency level of the hotels' economic activity. Considering the research findings, it is obvious that the industry would benefit from ampler and more sustained information campaigns on the EU Ecolabel.
\end{abstract}

Keywords: tourism; environmental impact; UE Ecolabel; management; Romania

\section{Introduction}

Tourism has proved to be a robust industry after its spectacular recovery from the world economic crisis of 2007-2008. The latest data provided by the World Tourism Organization [1] confirm the resilience and boost of the industry, a sector accounting for 10\% of the world's GDP, $7 \%$ of global trade and one in ten jobs. Due to its continuous and constant expansion, tourism has gained a vital role in global and social development, with an obvious and significant environmental impact.

Since the 1980s, specialists have emphasized the potential negative impact of the tourism industry on the environment, particularly because of the extensive use of natural and anthropic resources [2-6], pollution caused by the intensive tourism flows, and rapid development of tourism facilities $[7,8]$.

Starting with the works of Ceballos-Lascurain [9] and Romeril [10], the concepts of ecotourism, sustainable tourism, and responsible tourism have received broad attention from researchers, governmental bodies, international tourism organizations, consumers, and tourism enterprises. The emergence and implementation of various environmental tools and certification schemes, aimed at 
reducing the impact of tourism and promoting green practices in general tourism management, have therefore come as a natural consequence. The tourism industry has witnessed a great proliferation of these certification schemes and programs-if more than 70 were identified at the beginning of the 21st century [11], at present, there are more than 150 such schemes and programs [12]. It has led to increased interest from academics, who have developed studies addressing different tourist subindustries (accommodation, transport, food services, etc.) and several issues related to environmental measures-the certification process (steps to be taken, difficulties in implementation, financial concerns, duration, ethical considerations), general tourism businesses management, and consumer perceptions [13-17]. One of these areas of interest is in the EU Ecolabel, the unique official environmental label of the European Union, certified by an independent organisation and valid throughout Europe. Therefore, the present article focuses on the hotel managers' opinions about the EU Ecolabel, the challenges they face as far as environmental issues are concerned, and the prospects for more environmentally responsible tourism in the area.

The objectives of the present research are:

- To classify the most common environmental measures implemented in the accommodation units on the Romanian seaside;

- To reveal the measures pending implementation in the next years;

- To observe the level of the managers' awareness regarding the EU Ecolabel;

- To gain knowledge on the reasons why the EU Ecolabel was not applied for by the Romanian hotel managers, the criteria considered the most difficult to implement given the particularities of the seaside tourism, and the managers' perceptions on the impact that the EU Ecolabel has on activity efficiency;

- To investigate the factors influencing the intention to meet the criteria and to obtain the EU Ecolabel by the hotels on the Romanian seaside, and to this end, a model will be proposed.

The paper is organized as follows: Section 2 is devoted to the conceptual framework, Section 3 presents the methodology adopted in this study, Section 4 contains the results and discussions, and the last section concludes the work.

\section{Conceptual Framework}

The scientific research has detailed multiple facets of the implementation of environmental protection measures. Investigations regarding the voluntary or mandatory nature of such measures suggested that hotels voluntarily embracing green policies obtained better results [13]. Several works [14-21] analysed the economic advantages that such measures bring to tourism businesses and revealed mixed results. In some cases, the empirical studies unveiled advantages, such as the reduction of water and energy consumption, or even the positive relationship between the implementation of a certification scheme and tourism firm efficiency [14-17]. Other studies provided evidence that there were registered significant differences in the economic performance of certified hotels compared to those not certified [18] and that the environmental responsibility is strongly and positively related to firm performance [19]. However, the findings revealed that tourism managers are not convinced that holding a certification would automatically yield financial benefits [20], or market advantage [21].

Numerous empirical studies [22-28] conducted on the tourist accommodation industry showed that in the case of eco-friendly hotels (whether the respective hotels had an environmental certification or just implemented environmental protection measures) a positive influence on consumer decision was frequently recorded; however, depending on the country/region where the study had been conducted, different results were revealed. Certain investigations regarding the effects of the eco-friendly measures taken by the hotels' management concluded that their presence influenced the intention to choose the hotel, to have a longer stay, and even to pay more [22,23]. Millar and Baloglu [24], in a study conducted in the USA, observed that consumers appreciate eco-friendly functionalities such as the re-use policies for towels and linens and the electronic efficiency control of power use when they chose 
accommodation. On the other hand, several studies identified different consumer behaviour. In a study about the Polish customers, Bohdanowicz [25] concluded that the environmental certification or the eco-friendly measures for an accommodation facility are less important than the price and the location of the holiday destination. Kasim [26] and Volsky, Ozanne, and Fontenot [27] show that even though customers are aware of the concern and necessity of environmental protection, they consider other criteria as more important when choosing their holiday accommodation. The study conducted by Blamey, Bennett, Louviere, and Morrison [28] revealed the same contradiction between the fact that most consumers are concerned about the necessity to protect the environment and that the purchase decision seems to take no account of the eco-friendly facilities or ecolabels.

The scientific studies deal in most cases with the plethora of certification schemes and programs as an ensemble covering the environmental perspective related to the tourism industry, without singling out one or another of these schemes and programs and without elaborating on them as individual certification schemes. In this paper, we focus on ecolabelling, with a particular interest in the EU Ecolabel in tourist accommodation, which is the voluntary European initiative implemented after 2003 in order to attest to the responsible attitude towards the environment [29].

As with the other certification schemes, ecolabelling initiatives have grown since the mid-1970s, when the first ecolabelling scheme was implemented. The authors preoccupied with studying the ecolabel implementation process [30-34] emphasized that the main motivation of tourism enterprises to obtain such a certification is the image delivered to customers-an environmentally friendly business. Studies on the impact of ecolabelling have focused on several directions: the advantages of ecolabelling for tourism companies, tourism industry, and tourists [35,36], the difficulties that companies face when trying to obtain such a certification, and the impact of holding an ecolabel on the consumers' decision $[17,37]$. There are also less investigated aspects, such as those regarding the real advantages that an ecolabel brings to tourism businesses, although the theoretical advantages are listed in several research works $[35,38]$. Other aspects that are even less studied are represented by the opinions of the managers from the hospitality industry regarding the necessity to obtain an ecolabel. Covering this research area are the works of Dziuba [36], Ryglova [39], and Duglio et al. [40].

Therefore, we investigated the hotel managers' opinions concerning the balance between marketing considerations, competitive advantage, and technical or financial constraints, focusing on the hotel industry from the Romanian seaside.

The research on the topic in Romania reveals a situation that is similar to that identified in international research - several general aspects regarding certifications were investigated, while the particular case of the EU Ecolabel received less attention. The challenges related to ecolabel implementation, the consumer behaviour regarding ecolabeled tourism accommodation units or the hotel managers' perspective towards the advantages and the challenges of having an ecolabel certification are, at present, insufficiently researched at the Romanian tourism industry level. In their study conducted in Brasov on the customer's interest in eco-certified accommodation, Constantin, Ispas, and Candrea [41] found that $47 \%$ of the tourists from the investigated sample were interested in choosing an eco-certified hotel. Candrea and Bratucu [42] investigated the Romanian tourism managers' opinion about the implementation of environmental protection measures, and the results showed that most of the interviewed managers lacked knowledge on the existence of environmental management systems and certification schemes, but were interested in energy saving measures. The authors considered that the low response rate of the accommodation unit managers invited to participate in the survey showed little interest in environmental protection measures. One of the few articles focusing on the EU Ecolabel in the Romanian hotel industry [37] tested several hypotheses regarding customer perception. The research investigated customer awareness regarding the Ecolabel, the opinion about the presence of the Ecolabel as related to the quality of the services provided by the hotel, the willingness to pay more for the services offered by an ecolabeled hotel. Over $75 \%$ of the respondents had no knowledge about the Ecolabel. Moreover, customers tended to associate the presence of the Ecolabel primarily to the image of the hotel and not to the quality of the services. 
Only $15 \%$ of the respondents stated that they were willing to pay more due to the existence of the EU Ecolabel. Another study [43] investigated the managers' willingness to comply with the criteria and apply for obtaining the EU Ecolabel in Natura 2000 Crişul Repede Gorge-Pădurea Craiului Pass site and revealed positive attitudes among operators to meet the requirements for EU Ecolabel awarding. The study also reported that managers viewed the Ecolabel as a promotion vector that differentiated a tourism business from its competitors.

\section{Materials and Methods}

\subsection{Research Hypotheses}

Two research hypotheses were formulated and tested using the Chi-square test.

Hypothesis 1. The efficiency of the hotel's activity significantly influences the decision to implement additional environmental protection measures in the next three to five years.

Jarvis et al. [20] cited Medina (2005), Mycoo (2006), and Vertinsky and Zhou (2000) in order to emphasize that the implementation of environmental protection measures and applying for a certification scheme were usually associated with high costs for the tourism business, which could hinder this endeavour. Therefore, our assumption was that the efficiency of the economic activity affected the decision to implement environmental measures.

Hypothesis 2. The hotel classification category significantly influences the decision to implement additional environmental protection measures in the next three to five years.

The only two hotels in Romania holding the EU Ecolabel are a five-star and a four-star hotel, respectively. The other five-star hotels generally hold some sort of environmental certification. On the other hand, one or two-star hotels with environmental certifications are rather exceptions. Our interest was, therefore, to find out if the managers are influenced by the classification category of their hotel when they consider implementing additional environmental protection measures.

To reveal natural groupings within the sample of hotel managers, a cluster analysis was performed in IBM SPSS Statistics 23, using the Two Step algorithm. This algorithm was preferred due to its ability to generate clusters using both categorical and continuous variables. Two predictors were used: a. the reasons for not applying for the EU Ecolabel, and b. the presumed impact of ecolabelling on the efficiency of the hotel's activity. The economic efficiency of the hotel's activity represented the assessment field. For a further reference on the Two Step cluster analysis in SPSS please see [44].

\subsection{Sample Selection}

To achieve the objectives, the research targeted hotel managers and was conducted between November and December 2018. The research was aimed at the managers of the hotels established in the tourist resorts from the Northern Romanian seaside and in Constanta city (Figures 1 and 2). The choice of the seaside tourism region for the research was sustained by the importance of the seaside within the national tourism of Romania. 


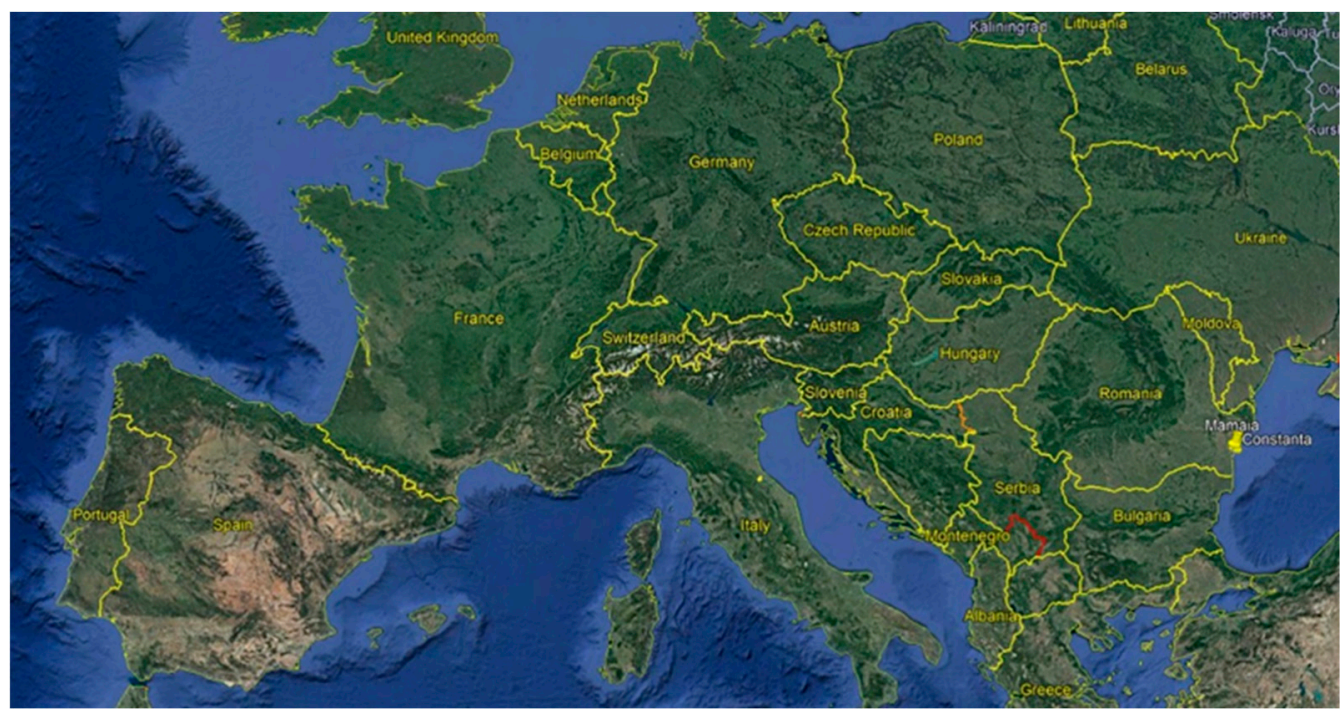

Figure 1. Map of Europe and the location of Constanta city in the South-East of Romania. Source: Google Earth Pro.

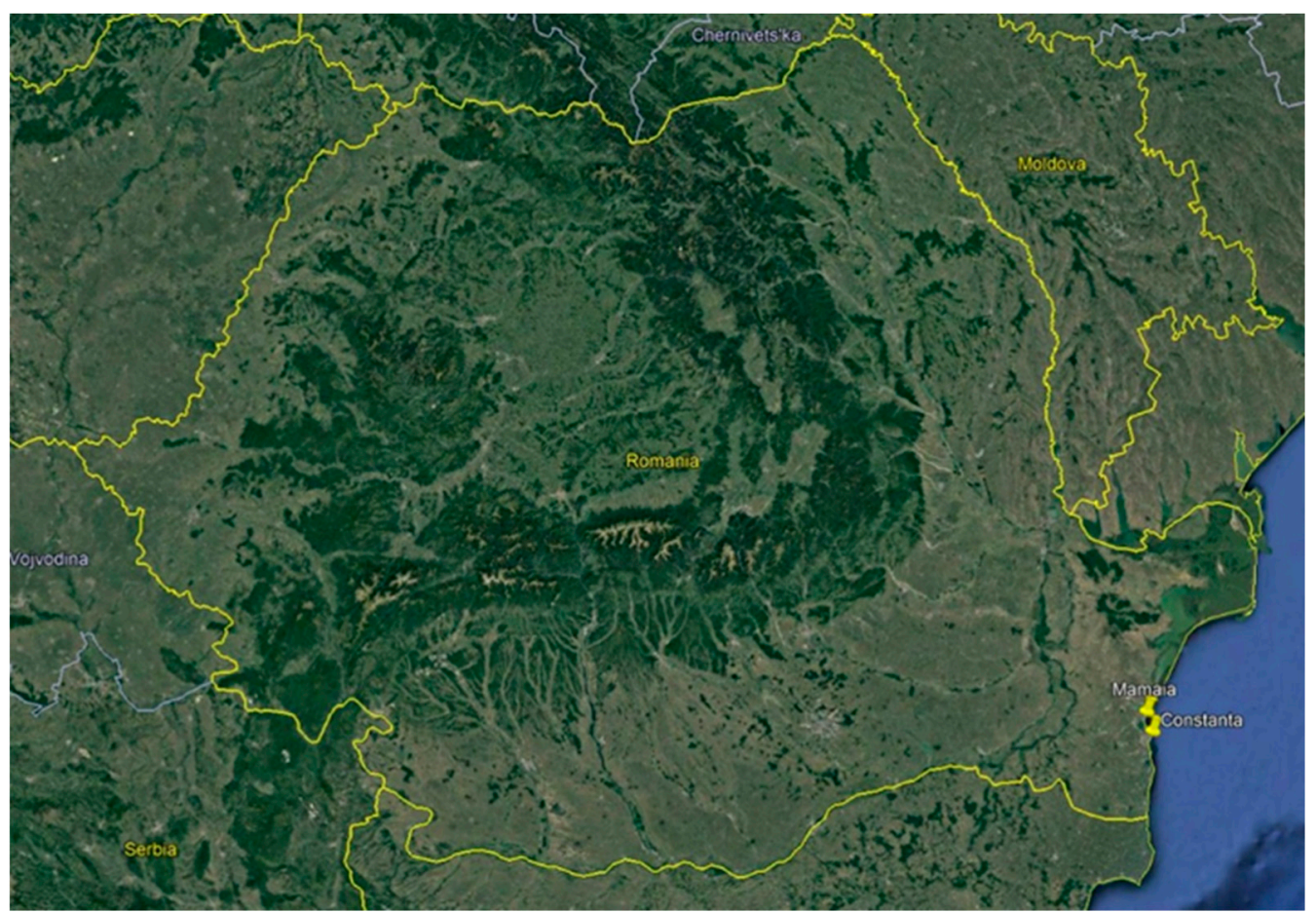

Figure 2. Map of Romania and the location of Constanta city. Source: Google Earth Pro.

The sample was compiled using proportionate stratification sampling, based on the statistical information regarding the number and classification of the hotels from the seaside tourist resorts, provided by the County Statistics Directorate. Proportionate stratification is a type of stratified sampling where each stratum has the same sampling fraction. The population is divided into separate groups and a sample is drawn from each group. Therefore, the hotels were grouped by their classification and proportional subsamples were extracted from each classification category. Subsequently, hotel managers of hotels in each classification category were approached by telephone and e-mail, until the sample was compiled. Once a hotel manager answered positively to the invitation to participate in the research, a meeting was scheduled with one of the authors of the article. 
The sample size, $n$, was computed using Yamane's formula [45]:

$$
n=\frac{N z_{\alpha}^{2} p(1-p)}{z_{\alpha}^{2} p(1-p)+N e^{2}}
$$

where $N$ is the population size, $z_{\alpha}$ is the z-score, $e$ is the margin error, and $p$ is the probability to obtain an affirmative answer to the question addressed.

In this study, $N=107$ (according to the official statistics provided by the County Statistics Directorate for the year 2017), $z_{\alpha}=1.96$, corresponding to a confidence level of $95 \%, e=0.089, p=0.5$.

\subsection{The Questionnaire}

The research instrument was a questionnaire, and in order to ensure the proper understanding of the research scope and the completeness of the information provided, the respondents filled in the questionnaires during a scheduled meeting with one of the authors of this article.

The questionnaire integrated four sections. The first section focused on obtaining information on the environmental measures that had been already implemented by the accommodation unit, the ones pending implementation in the near future, and the existence of any kind of ecological certification. The respondents' degree of familiarity with the EU Ecolabel was subsequently targeted, using a five-point semantic differential, from 1 (very little familiarized) to 5 (very familiarized). Since none of the respondents indicated a high degree of familiarity with the EU Ecolabel, the authors delivered a short presentation of the mandatory and optional criteria for ecolabel awarding.

The second section focused on obtaining information on whether applying for the EU Ecolabel was considered, and if not, what were the reasons why the management did not take it into consideration; questions were also asked about the criteria that would be the most difficult to meet.

The third section of the questionnaire focused on the managers' views and opinions on customer cognition of the matter and on the perceived impact of the ecolabel on the economic activity of the accommodation unit. The managers gave their opinion on the customers' perception of ecolabeled accommodation units. Subsequently, three-point semantic differentials from 1 (very unlikely to be a criterion) to 3 (very likely to be a criterion) were used to assess the managers' opinion on whether the environmental protection measures represent a criterion for choosing hotel accommodation, by both Romanian and foreign tourists. Next, a five-point Likert-type scale was used to assess the managers' opinions whether during the next 3-5 years the EU Ecolabel would become a major criterion for customers when choosing their accommodation. Also, a five-point Likert-type scale was used to assess whether the managers considered that holding the EU Ecolabel would have a positive impact on the economic efficiency of the hotel's activity. Finally, the managers' intention to meet the criteria and obtain the EU Ecolabel was investigated, using a scale from 1 (little interested) to 5 (very interested).

The last section was directed toward obtaining general information about the respondents, such as their age, gender, education, and work experience in tourism.

\subsection{Modelling}

Based on the collected data, a multiple linear regression model was determined for the dependence between the declared intention to meet the criteria and obtain the EU ecolabel $(\mathrm{Y})$ and the managers' level of knowledge about the EU Ecolabel $\left(Z_{1}\right)$, their opinion on whether ecolabelling represents a competitive advantage $\left(Z_{2}\right)$, and the current efficiency level of the hotel's economic activity $\left(Z_{3}\right)$ :

$$
Y=\beta_{1} Z_{1}+\beta_{2} Z_{2}+\beta_{3} Z_{3}+\xi
$$

where $\xi$ is the residual variable.

The data summary is available as Supplementary Materials.

The model was tested for accuracy using the following tests: (1) the Student t-test, for the significance of coefficients, (2) the F-test for the model's significance, (3) the Kolmogorov-Smirnov 
test for the residual's normality, (4) the F-test and the Levene test for the residual's homoscedasticity. The correlogram was also built to study the residuals' autocorrelation [46-48]. The determination coefficient was also provided.

\section{Results and Discussions}

Table 1 contains the characteristics of the sample targeted in our study. Most of the respondents were women, i.e., $61.7 \%$. As far as the age was concerned, the majority of the respondents $(46.7 \%)$ were $36-45$ years old. One may easily notice that more than $70 \%$ of the respondents were less than 45 years old.

Table 1. Characteristics of the sample.

\begin{tabular}{|c|c|c|c|c|c|}
\hline \multirow[t]{3}{*}{$\%$} & \multicolumn{2}{|c|}{ Gender } & \multicolumn{3}{|c|}{ Studies } \\
\hline & Female & Male & Elementary education & Bachelor & Post-university \\
\hline & 61.7 & 38.3 & 6.7 & 41.7 & 51.6 \\
\hline \multicolumn{6}{|c|}{ Age (years) } \\
\hline & $18-25$ & $26-35$ & $36-45$ & $46-55$ & $56-65$ \\
\hline & 8.3 & 20 & 46.7 & 20.0 & 5.0 \\
\hline \multicolumn{6}{|c|}{ Experience in tourism (years) } \\
\hline & $0-5$ & $6-10$ & $11-15$ & $16-20$ & $>20$ \\
\hline & 10.0 & 31.7 & 35.0 & 13.3 & 10.0 \\
\hline
\end{tabular}

Thirty-five percent of the respondents had between 11 and 15 years of work experience in tourism, $31.7 \%$ had between six and ten years, $13.3 \%$ had between 16 and 20 years, while $10.0 \%$ had more than 20 years of experience in tourism.

Most respondents (51.6\%) stated they were post-graduate university graduates (master's or doctorate degree), followed by university (BA) graduates (41.7\%).

In this study, we relied on the perceived efficiency of the economic activity of the hotels. The managers were invited to assess the efficiency of the economic activity of the hotel, based on the results from the previous two years, in terms of income and expenditure. Considering the efficiency of the economic activity of the hotels included in the sample, the hotels were grouped into three categories-low efficiency (group 1), medium efficiency (group 2), and high efficiency (group 3). This yielded the following structure of the sample: group $1-8.3 \%$; group $2-53.3 \%$; group $3-38.3 \%$.

One of the pursuits of our research was to classify the most common environmental measures already implemented by hotels and to discover whether the hotel management had other environmental measures planned for the next three to five years. The results revealed that in most hotels the environmental measures implemented targeted the reduction of energy consumption, with $58.3 \%$ of the hotels having taken such measures. Secondly, $36.7 \%$ of the hotels targeted water consumption, followed by waste $(26.7 \%)$.

The research revealed that most of the hotels $(73.3 \%)$ were planning to implement other environmental measures during the next three to five years. These measures targeted energy saving $(43.3 \%)$, water consumption $(40.0 \%)$, waste reduction $(26.7 \%)$, and hazardous chemical products $(11.7 \%)$.

At the time of the research, only four hotels had an ecological certification well established in the field of tourism, other than the EU Ecolabel. However, in two cases the certification, although well established, was not related to the accommodation services provided.

When asked how familiar they were with the EU Ecolabel, most managers (48.3\%) indicated that they were little familiarized; $23.3 \%$ had no previous knowledge of the issue, and $28.3 \%$ were moderately familiarized with the EU Ecolabel. None of the managers asserted that they had solid knowledge of the EU Ecolabel. The results confirmed other findings identified in the literature $[39,42,43]$. It is 
worth mentioning that the necessity to raise awareness on the EU Ecolabel is a current concern of the European responsible bodies [29].

The research then aimed at finding whether the hotel had previously considered applying for the ecolabel; if it did not, we aimed to identify the reasons behind this decision. Only five managers claimed that the hotel had previously considered applying for the EU Ecolabel, and eight said that they did not have information on whether applying for the ecolabel was considered or not. Most respondents, i.e., $47(78.3 \%)$, stated that applying for the ecolabel was not previously taken into consideration. The most cited reasons for not considering applying for the ecolabel were the lack of information on the EU Ecolabel (38.3\%), the difficulty in meeting the criteria (33.3\%), and the customers' lack of awareness regarding the Ecolabel $(20.0 \%)$. Other reasons included the costs of the certification and holding other types of ecological certification. Focusing on the Ecolabel criteria, the managers considered that the most difficult to comply with was the energy criterion (41.7\%), followed by waste reduction (28.3), water consumption $(18.3 \%)$, as well as general management $(15.0 \%)$.

The majority of the managers $(88.3 \%)$ were convinced that holding the EU Ecolabel would represent a competitive advantage for the hotel. This finding is in line with previous studies, which revealed that generally, the environmental protection measures were considered a source of competitive advantage [20].

The research focused next on the managers' opinion regarding the tourists' perceptions of the Ecolabel. Most of the respondents (26.7\%) singled out the role of the Ecolabel in building company reputation, while $23.3 \%$ considered that the Ecolabel might endorse service quality. $21.7 \%$ of the respondents viewed it as a marketing element, while the rest considered that the clients were not interested in the matter and they perceived the EU Ecolabel more as expense rather than advantage.

The next two research questions focused on whether managers considered that the environmental measures implemented by hotels and advertised to customers, represented a criterion for choosing accommodation for Romanian and foreign tourists, respectively. A three-point semantic differential was used in order to assess the managers' opinions, from 1 (very unlikely to be a criterion) to 3 (very likely to be a criterion). The results indicated that managers considered foreign tourists to be slightly more inclined to choose accommodation based on hotel environmental measures than the Romanian ones, with a mean score of 1.97 for foreign tourists, and 1.35 for Romanian tourists. However, managers did not foresee a dramatic change in the consumers' attitude in the next years. On a five-point Likert-type scale (from -2 completely disagree to +2 completely agree), the opinion regarding whether the EU Ecolabel would become an important criterion for choosing hotel accommodation during the next three to five years was assessed. The mean score of 0.11 indicated that managers were rather sceptical about the prospective role of the Ecolabel in tourist behaviour. This is consistent with the previous research conducted both in Romania [37], and worldwide [49].

We then assessed the managers' opinion on whether fulfilling the environmental criteria and receiving the EU Ecolabel would have a positive impact on the economic efficiency of the activity. A five-point Likert-type scale (from -2 completely disagree to +2 completely agree) was used. The mean score of 1.00 indicated that managers presumed that the Ecolabel would have a positive impact on the efficiency of the hotel's activity. Previous results on economic efficiency related issues revealed mixed results-in some cases the managers considered that the environmental protection measures had a positive impact $[14,15,18,19]$, while others expressed their doubts regarding a positive impact [20].

The results of the tested hypothesis are the following:

For Hypothesis $1, \chi^{2}(2)=11.403, p=0.003$, indicating that the efficiency of the hotel's activity significantly influences the decision to implement additional environmental measures in the next three to five years.

For Hypothesis $2, \chi^{2}(4)=2.852, p=0.583$, revealing that the hotel classification category does not significantly influence the decision to implement additional environment protection measures in the next three to five years. 
Using the Two-Step algorithm and based on the two predictors, the reasons for not applying for the EU Ecolabel and the presumed impact of ecolabelling on the efficiency of the hotel's activity, and choosing - as assessment field—the economic efficiency of the hotel's activity, three clusters resulted, covering $39.7 \%, 34.5 \%$, and $25.9 \%$ of the study data.

The cluster quality was good, based on a silhouette coefficient of cohesion and separation of 0.6. The size of the smallest cluster was 15 (25.9\%) and the size of the largest one was 23 (39.7\%). The ratio of sizes was satisfactory (1.53).

The first cluster includes the managers who considered that the most important reason for not applying for the EU Ecolabel was their lack of information and knowledge regarding the certification and found that holding the EU Ecolabel would have a low to moderate impact on the efficiency of the economic activity. The second cluster includes the managers who considered the difficulty of meeting the criteria as a reason for not applying for the EU Ecolabel and found that holding the EU Ecolabel would have a moderate impact on the efficiency of the economic activity. The third cluster includes the managers who considered that the customers' lack of awareness was the main reason for not considering applying for the EU Ecolabel, and that holding the EU Ecolabel would have a strong impact on the efficiency of the economic activity.

The modelling results are provided in Table 2 and Figures 3-5.

Table 2. Coefficients of the variables in the regression model.

\begin{tabular}{ccccc}
\hline Variables & Coefficients & Standard Error & t Stat & $p$-Value \\
\hline$Z_{1}$ & 0.70649 & 0.10925 & 6.46628 & $2.45 \times 10^{-8}$ \\
$Z_{2}$ & -0.37611 & 0.16943 & 7.865639 & 0.03042 \\
$Z_{3}$ & 0.73392 & 0.10549 & 2.502161 & $3.743 \times 10^{-9}$ \\
\hline
\end{tabular}

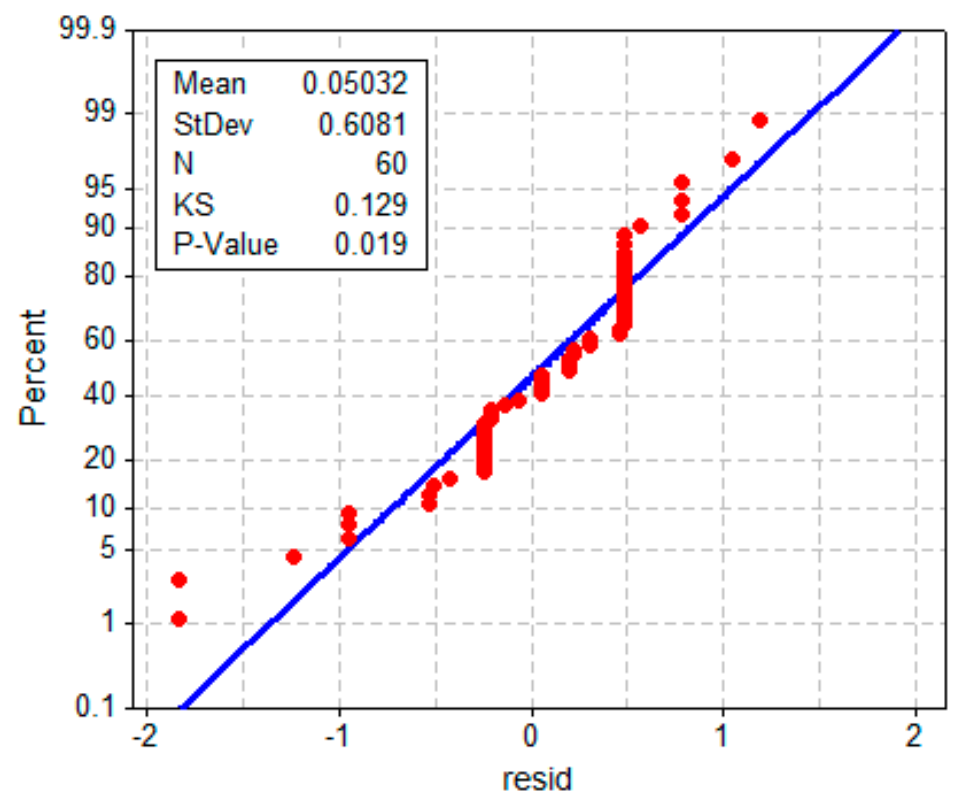

Figure 3. Normal probability plot for the residuals in the model. The line represents the theoretical distribution and the dots represent the actual data.

The coefficients of the variables are in the second column of Table 2, the values of the Student $\mathrm{t}$-statistics are presented in the fourth column, and the corresponding $p$-values are in the fifth column. Since the $p$-values are all less than 0.05 , all of the coefficients of the model are significant.

The F-test did not reject the hypothesis regarding the significance of the model as a whole because the $p$-value corresponding to the F statistics is $2.94 \times 10^{-38}(<0.05)$.

The analysis of residuals was also performed. 
The Kolmogorov-Smirnov test did not reject the hypothesis that the residuals are normally distributed at the significance level of 0.01 since the $p$-value associated is $0.019>0.01$ (Figure 3).

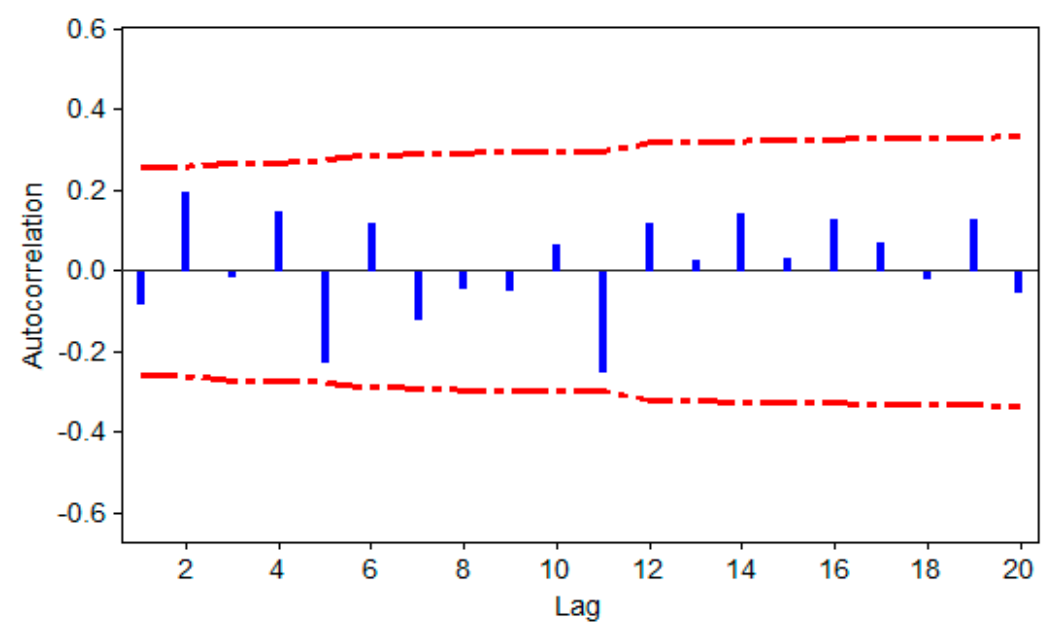

Figure 4. The correlogram of the residuals (with 5\% significance limits for the autocorrelations).

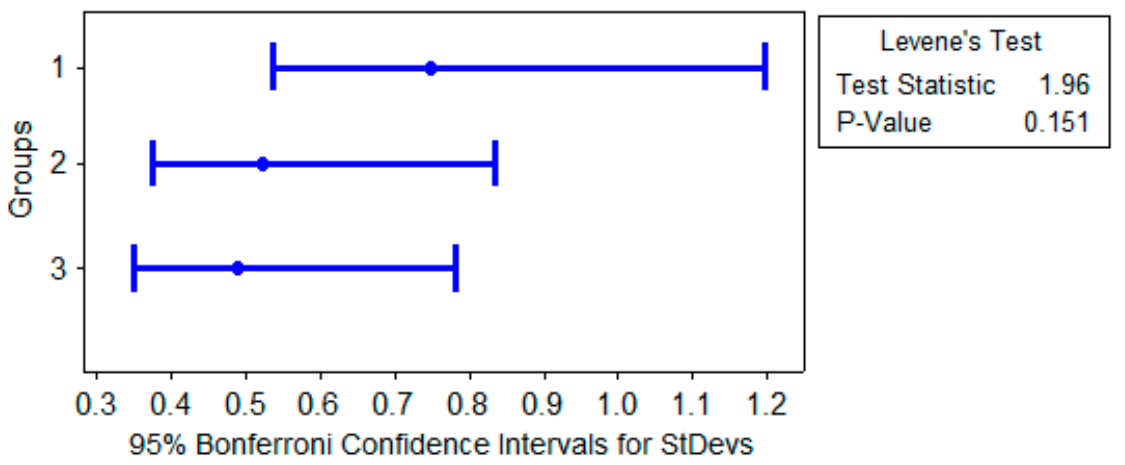

Figure 5. Results of the Levene test for the residual in the model.

The correlogram analysis does not emphasize the existence of the residuals autocorrelation, as one may observe in Figure 4, where the vertical bars represent the values of autocorrelation functions at different lags and the dotted line represents the limits of the empirical confidence interval at $95 \%$ confidence level.

As the residuals are Gaussian and not correlated, they are independent. They are also homoscedastic since the $p$-value corresponding to the Levene test are greater than 0.05 (Figure 5).

The value of the determination coefficient $\left(R^{2}=0.9564\right)$ confirms the existence of a strong relationship between the dependent and independent variables. Therefore, the model:

$$
Y=0.706 Z_{1}-0.376 Z_{2}+0.734 Z_{3}+\xi
$$

is statistically correct, describing the intention to meet the criteria and obtain the EU Ecolabel $(Y)$, the function of the managers' level of knowledge about the EU Ecolabel $\left(Z_{1}\right)$, their opinion on whether ecolabelling represents a competitive advantage $\left(Z_{2}\right)$, and the current efficiency level of the hotel's economic activity $\left(Z_{3}\right)$.

\section{Conclusions}

Tourism is one of the most dynamic economic sectors and is extremely environmentally challenging. The scientific literature on the tourism accommodation industry and environmental related issues is abundant in studies concerned with the way tourism businesses should implement environmental protection measures and obtain a certification. At the same time, a similar scientific 
interest is paid to the customers' appreciation of the accommodation units awarded with such a certification. Less studied perspectives are those related to whether these eco-certifications bring real benefits to tourism businesses and the hotel managers' opinion on obtaining a certification in terms of the opportunities to increase their income and maintain profitability. Our research investigates precisely one of these less studied perspectives, that is, the managers' opinion regarding environmental protection measures and their appreciation of the impact a certification would have on the hotel economic activity, with an emphasis on the EU Ecolabel. The situation in Romania, where there are only two hotels holding the EU Ecolabel, is consistent with that of other countries in Central and Eastern Europe (Poland, Hungary, Greece, Bulgaria) and in contrast with several Western and Southern European countries (Italy, France, Spain, Austria). Therefore, the aim of the research was to investigate the tourism managers' perspective, who are, in the end, the decision-making factors in adopting environmental friendly measures and obtaining certifications.

The research proposed five objectives, which were attained. The research results revealed that the most common environmental measures implemented in the Romanian seaside hotel industry targeted the reduction of energy consumption, followed by water consumption, and waste. The research also showed that most hotels are planning to implement other environmental measures during the next three to five years, especially targeted at energy saving, water consumption, waste reduction, and hazardous chemical products.

A significant conclusion of our research is that most managers are convinced that the EU Ecolabel represents a competitive advantage for the hotel, which is in line with previous findings [20]. However, most managers had never considered applying for the EU Ecolabel. The most cited reasons for not applying are the lack of information about the EU Ecolabel, the difficulty of the criteria (especially the energy, waste, and water criteria), the customers' lack of awareness and interest regarding the ecolabel. These findings confirm the results of the previous studies on the managers' lack of information about the EU Ecolabel [39,42], the customers' attitude [26,28,37,49], and the high implementation costs (Medina, 2005; Mycoo, 2006; Vertinsky and Zhou, 2000, cited in [20]). Bearing in mind the research findings, it is our strong belief that the entire hotel industry would benefit from coherent and sustained information campaigns on the EU Ecolabel.

In accordance with the results of previous studies on the consumers' perception of the accommodation units with an environmental certification [25-28,37], the managers were rather sceptical about the prospective role of the EU Ecolabel in tourist behaviour. Moreover, they considered foreign tourists to be slightly more inclined to choose accommodation based on the existence of environmental protection measures than the Romanian ones.

The novelty of our research resides in investigating the factors that influence the managers' decision to implement additional environmental measures during the next years, meet the criteria, and apply for obtaining the EU Ecolabel. The results indicated that the efficiency of the hotel's activity significantly influences the decision to implement additional environmental measures during the next years, while the hotel classification category does not. Finally, yet importantly, the constructed and tested model confirmed that the decision to meet the criteria and obtain the EU Ecolabel depends significantly on the managers' knowledge of the EU Ecolabel, their opinion on whether ecolabelling represents a competitive advantage, and the current efficiency level of the hotel's economic activity.

Given the obtained results, a future research direction would be to investigate the opinions of the Bulgarian seaside tourism managers, bearing in mind the similarities between Bulgaria and Romania concerning seaside tourism.

Supplementary Materials: The following are available online at http:/ /www.mdpi.com/2071-1050/11/1/265/s1.

Author Contributions: The contributions of the authors at the article are as follows: questionnaire design and data collecting A.-D.M. and C.D., methodology-A.-D.M. and A.B., modeling and validation-A.B. and A.-D.M., formal analysis-C.D., investigation-C.D., writing-original draft preparation, A.B., A.-D.M. and C.D.

Funding: This research received no external funding.

Conflicts of Interest: The authors declare no conflict of interest. 


\section{References}

1. World Tourism Organization. UNWTO Annual Report 2015. 2016. Available online: https:/ /www.e-unwto. org/doi/pdf/10.18111/9789284419807 (accessed on 10 October 2018).

2. Cohen, E. The impact of tourism on the physical environment. Ann. Tourism Res. 1978, 5, 215-237. [CrossRef]

3. Obua, J.; Harding, D.M. Environmental impact of ecotourism in Kibale National Park, Uganda. J. Sustain. Tourism 1997, 5, 213-222. [CrossRef]

4. Wen, J. Evaluation of tourism and tourist resources in China: Existing methods and their limitations. Int. J. Soc. Econ. 1998, 25, 467-485. [CrossRef]

5. Christensen, A.M.; Beckmann, S. Consumers' Perspectives on Tourism and the Environment. CEC Working Paper No. 7. 1998. Available online: https:/ / www.researchgate.net/profile/Suzanne_Beckmann/ publication/228719926_Consumers \T1 \textquoteright_Perspectives_on_Tourism_and_the_Environment/ links/09e4150afaf627e598000000.pdf (accessed on 17 March 2018).

6. Gössling, S. The consequences of tourism for sustainable water use on a tropical island: Zanzibar, Tanzania. J. Environ. Manag. 2001, 61, 179-191. [CrossRef] [PubMed]

7. Liu, J.C.; Var, T. Resident attitudes toward tourism impacts in Hawaii. Ann. Tourism Res. 1986, 13, $193-214$. [CrossRef]

8. Ahn, B.Y.; Lee, B.K.; Shafer, C.S. Operationalizing sustainability in regional tourism planning: An application of the limits of acceptable change framework. Tourism Manag. 2002, 23, 1-15. [CrossRef]

9. Ceballos-Lascurain, H. The future of ecotourism. Mexico J. 1987, 1, 13-14.

10. Romeril, M. Tourism and the environment-towards a symbolic relationship. Int. J. Environ. Stud. 1985, 25, 215-218. [CrossRef]

11. Font, X.; Sanabria, R.; Skinner, E. Sustainable tourism and ecotourism certification: Raising standards and benefits. J. Ecotourism 2003, 2, 213-218. [CrossRef]

12. Plüss, C.; Zotz, A.; Monshausen, A.; Kühhas, C. Sustainability in tourism. A guide through the label jungle. Available online: https: / destinet.eu/who-who/civil-society-ngos/ecotrans/publications/guide-throughlabel-jungle-1/ (accessed on 7 January 2019).

13. Bagur-Femenias, L.; Celma, D.; Patau, J. The Adoption of Environmental Practices in Small Hotels. Voluntary or Mandatory? An Empirical Approach. Sustainability 2016, 8, 695. [CrossRef]

14. Bhaskaran, S.; Polonsky, M.; Cary, J.; Fernandez, S. Environmentally sustainable food production and marketing. Br. Food J. 2006, 108, 677-690. [CrossRef]

15. Tzschentke, N.; Kirk, D.; Lynch, P.A. Reasons for going green in serviced accommodation establishments. Int. J. Contemp. Hosp. Manag. 2004, 16, 116-124. [CrossRef]

16. Butler, J. The Compelling “Hard Case" for "Green" Hotel Development. Cornell Hosp. Q. 2008, 49, $234-244$. [CrossRef]

17. Zhang, J.; Joglekar, N.; Verma, R.; Heineke, J. Exploring the Relationship between Ecocertifications and Resource Efficiency in U.S. Hotels. Research paper. 2014. Available online: http:/ /scholarship.sha.cornell. edu / cgi/viewcontent.cgi?article=1172\&context=chrpubs (accessed on 9 August 2018).

18. Segarra-Oña, M.; Peiró-Signes, A.; Verma, R.; Miret-Pastor, L. Does Environmental Certification Help the Economic Performance of Hotels? Evidence from the Spanish Hotel Industry. Available online: http:// scholarship.sha.cornell.edu/cgi/viewcontent.cgi?article=1048\&context=articles (accessed on 9 August 2018).

19. Rodriguez, F.J.G.; del Mar Armas Cruz, Y. Relation between social-environmental responsibility and performance in hotel firms. Hosp. Manag. 2007, 26, 824-839. [CrossRef]

20. Jarvis, N.; Weeden, C.; Simcock, N. The benefits and challenges of sustainable tourism certification: A case study of the green tourism business scheme in the West of England. J. Hosp. Tourism Manag. 2010, 17, 83-93. [CrossRef]

21. Bonilla-Priego, M.J.; Nájera, J.J.; Font, X. Environmental management decision-making in certified hotels. J. Sustain. Tourism 2011, 19, 361-381. [CrossRef]

22. Han, H.; Hsu, L.T.; Lee, J.S.; Sheu, C. Are lodging customers ready to go green? An examination of attitudes, demographics, and eco-friendly intentions. Int. J. Hosp. Manag. 2011, 30, 345-355. [CrossRef]

23. Lee, W.H.; Moscardo, G. Understanding the impact of ecotourism resort experiences on tourists' environmental attitudes and behavioral intentions. J. Sustain. Tourism 2005, 13, 546-565. [CrossRef]

24. Millar, M.; Baloglu, S. Hotel Guests' Preferences for Green Guest Room Attributes. Cornell Hosp. Q. 2011, 52, 302-311. [CrossRef] 
25. Bohdanowicz, P. European hoteliers' environmental attitudes. Cornell Hosp. Q. 2005, 46, 188-204. [CrossRef]

26. Kasim, A. Socio-environmentally responsible hotel business: Do tourists to Penang Island, Malaysia care? J. Hosp. Leisure Mark. 2004, 11, 5-28. [CrossRef]

27. Volsky, R.P.; Ozanne, L.K.; Fontenot, R.J. A conceptual model of US consumer willingness to pay for environmentally certified wood products. J. Consum. Mark. 1999, 16, 122-140. [CrossRef]

28. Blamey, R.; Bennett, J.; Louviere, J.; Morrison, M. Validation of a Choice Model Involving Green Product Choice; Choice Modelling Research Report; The University of New South Wales: Sydney, Australia, 1999.

29. European Commission. EU Ecolabel Work Plan for 2016-2018. 2016. Available online: http: / / ec.europa.eu/ environment/ecolabel/documents/Work\%20plan\%202016-2018.pdf (accessed on 3 March 2018).

30. Grodsky, J. Certified green: The law and future of environmental labelling. Yale J. Regul. 1993, 10, 147-227.

31. Davis, G. How green the label? Forum Appl. Res. Public Policy 1997, 12, 137-140.

32. Kusz, J. Ecolabel investments: What's behind label? Forum Appl. Res. Public Policy 1997, 12, 133-136.

33. Shimp, R.; Rattray, T. Ecoseals: Little more than a pretty package. Forum Appl. Res. Public Policy 1997, 12, 128-132.

34. Sasidharan, V.; Sirakaya, E.; Kerstetter, D. Developing countries and tourism ecolabels. Tourism Manag. 2002, 23, 161-174. [CrossRef]

35. Eco-labels for Tourism in Europe: Moving the Market towards more Sustainable Practices. Ecotrans 2004: Tourism Forum International Reisepavillon. Available online: http:/ /www.ecotourism.org/onlineLib/ Uploaded/Eco-labels_tourism_Europe_Hamele.pdf (accessed on 15 April 2017).

36. Dziuba, R. Sustainable development of tourism-EU ecolabel standards illustrated using the example of Poland. Comp. Econ. Res. 2016, 19, 111-128. [CrossRef]

37. Lupu, N.; Tanase, M.O.; Tontoroiu, R.A. A straightforward x-ray on applying the ecolabel to the hotel business area. Amfiteatru Econ. 2013, XV, 634-644.

38. Font, X. Environmental certification in Tourism and hospitality: Progress, process and prospects. Tourism Manag. 2002, 23, 197-205. [CrossRef]

39. Ryglová, K. Eco-certification as a tool of sustainable tourism. Agric. Econ.-Czech 2007, 53, 138-143. [CrossRef]

40. Duglio, S.; Ivanov, S.; Magliano, F.; Ivanova, M. Motivation, costs and benefits of the adoption of the European Ecolabel in the tourism sector: An exploratory study of Italian accommodation establishments. IZVESTIYA J. Varna Univ. Econ. 2017, 61, 83-95.

41. Constantin, C.P.; Ispas, A.; Candrea, A.N. Identifying Tourists Interested in Eco-Certified Accommodation Units from Brașov, Romania. Manag. Dyn. Knowl. Econ. 2013, 1, 521-542.

42. Candrea, A.N.; Bratucu, G. The perspectives for environmental management in small and medium accommodation units. The case of Braşov, Romania. Manag. Mark. Challenges Knowl. Soc. 2012, 7, 465-478.

43. Ban, O.I.; Iacobaş, P.; Nedelea, A.M. Marketing research regarding tourism business readiness for eco-label achievement (Natura 2000 Crişul Repede Gorge-Pădurea Craiului Pass site). Revista Turism-Studii Cercetari Turism 2016, 5, 224-234.

44. Bacher, J.; Wenzig, K.; Vogler, M. SPSS twostep cluster: A first evaluation. 2004. Available online: https: / /www.statisticalinnovations.com/wp-content/uploads/Bacher2004.pdf (accessed on 10 February 2018).

45. Yamane, T. Statistics: An Introductory Analysis; Harper and Row: New York, NY, USA, 1967.

46. Bărbulescu, A.; Koncsag, C. A new model for estimating mass transfer coefficients for the extraction of ethanethiol with alkaline solutions in packed column. Appl. Math. Modell. 2007, 31, 2515-2523. [CrossRef]

47. Bărbulescu, A. Models for temperature evolution in Dobrogea. Rom. Rep. Phys. 2016, 68, 788-798.

48. Bărbulescu, A. Studies on Time Series. Applications in Environmental Sciences; Springer International Publishing: Cham, Switzerland, 2016; pp. 1-46, ISBN 3319808095.

49. Budeanu, A. Sustainable tourist behaviour-A discussion of opportunities for change. Int. J. Consum. Stud. 2007, 31, 499-508. [CrossRef]

(C) 2019 by the authors. Licensee MDPI, Basel, Switzerland. This article is an open access article distributed under the terms and conditions of the Creative Commons Attribution (CC BY) license (http:/ / creativecommons.org/licenses/by/4.0/). 